\title{
An Computerized Health Check Token System Engneering using Arduino Kit
}

\author{
K.Sivaraman, S. Neduncheliyan, K.P. Kaliyamoorthi
}

\begin{abstract}
The extensive system may expulsion to take as much time as crucial, or negligence that they have starting at now consumed their medications. From this time forward, they miss estimations of arrangement, or take overdoses. To manage this issue we spread out and amassed an electronic structure, which can be commonplace in an answer office with screen a person's confirmation of fixes. This pack is used as a touch of the ace's office or in the home to serve the patients and made who get fix. The server will record the season of taking arrangement, and as showed up by a chance to censure whether the made take game plan in time. It is powerfully basic for the made who consistently expulsion to take fix.
\end{abstract}

\section{Keywords: Prescription, Medication, Cabin}

\section{INTRODUCTION}

Number of inhabitants is developing quickly, develop continuously set they up make memory challenges. Therefore, dynamically arranged people may negligence to take as much time as imperative, or overlook that they have enough taken their answers.. To deal with this issue, we spread out and fabricated an electronic framework, which can be familiar in a medication specialist with screen a man's affirmation of arrangements. The framework criteria has take after (an) inconsequential effort, (b) settlement, (c) reliability, and (d) equivalence with various office sorts, and prescription containers significantly more especially, the headway offers strategies and structures to dealing with a man's response organization with a PC framework related with the database adjacent the sensor. [13], [15], [17]

Ordinary prescription organizers just give an instrument to securing a man's answer. Exactly when the prescription agency is arranged in a house in which a family lives, it isn't remarkable for the arrangement department to contain meds for different individuals from the family. This shows the probability that one individual may take prescription by chance that is embraced for a substitute person. In like manner, it isn't remarkable that a man will disregard to have an answer refilled until he takes the last pill of his drug. With the present clamoring lifestyles, individuals routinely take their medicines at an inappropriate time or in an inappropriate whole. In addition, individuals are every now and again not aware of new notification about opposing effects what's more, drug interchanges for different meds. It gives assistive sign to

Revised Manuscript Received on August 22, 2019.

K.Sivaraman Department of CSE,Bharath Institute of Higher Education \& Research,TamilNAdu Email: sivaraman2006@gmail.com

S. Neduncheliyan, Department of CSE,Bharath Institute of Higher Education \& Research,TamilNAdu Email: dean.cse@bharathuniv.ac.in

K.P. Kaliyamoorthi, Department of CSE,Bharath Institute of Higher Education \& Research,TamilNAdu Email: kpkaliyamurthie@gmail.com patients as prompts and refreshes and depicts our hardware and programming plan examinations of this therapeutic system for dealing with drug of individuals. [1],[3],[5]

The materials being broke down wire an arduino pack, sensor and drove lights for experimentation with the pill bottles. For programming, php and Java have been made GUI mechanical assemblies that can in like manner interface with both the gear and MySQL database.Arduino program jump in for the arduinokit.One of the burdens related to home visits is managing a very much arranged game plan that can be viably gotten to, fathomed and balanced. Generally this structure can made in master's office for patient-character as opposed to review the manual fix of a patient and recoup the information of a patient from the database. [7],[9],[11]

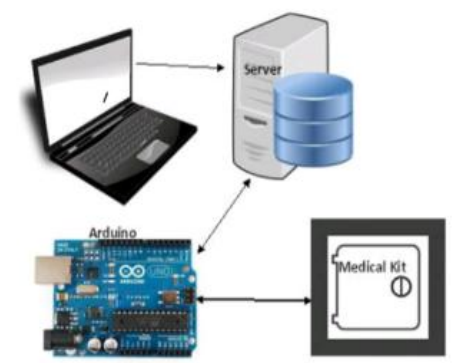

Fig: 1 Arduino Medical Kit

\section{BACKEND DATABASE}

The MySQL database fills in as a record of information. The majority of the information about every remedy holder and when it was seen is confirmed in this database. The instructive record away in the database are detached into different groupings as appeared by their chance to live. A dash of the data sorts are discarded toward the day's end, while other are kept for longer periods for later use. In test preliminaries the database find the opportunity to time was usually 0.00004 seconds which is inconceivably shrewd for the proposed application and does not raise any issues concerning the quick access of the database each time an event occurs. Other than when basic, the instructive accumulation away in the database could be changed over to whatever other relationship for looking at the data further. [14],[ 16], [18]

\section{INVESTIGATION OF THE ARDUINO TECHNOLOGY}

Arduino is an open-source PC gear and the customer pack that plans and passes on 
microcontroller-based units for structure modernized contraptions and adept things that can perceive and control the physical world.Thearduino relies on a get-together of microcontroller board plans made on a particularly basic level by Keen Ventures in Italy, and also by a couple of various merchants, using indisputable 8-bit Atmel AVR microcontrollers or 32-bit Atmel ARM processors. These structures give sets of modernized and clear I/O sticks that can be interfaced to various advancement sheets ("shields") and various circuits. The sheets feature back to back communciation interfaces, including USB on a couple of models, for stacking programs from PCs. For programming the microcontrollers, the Arduino stage gives a dealt with advancement condition. energized improvement condition (IDE) in setting on the Preparing knowledge, which joins support for C,C++ and Java programming tongues. The first Arduino was displayed in 2005 , meaning to give a prudent and basic course for novices and specialists to make contraptions that speak with their condition using sensors and actuators. Fundamental instances of such contraptions expected for authorities join essential robots, indoor controllers, and development pointers. Arduino sheets are open monetarily fit as a fiddle, or as do-it-without anybody's assistance units.

\section{PRESCRIPTION KIT ENHANCEMENT}

Here we base on using the arduino improvement to seek after the prescription taking behavior of the patient in light of the doubt that when a pills is taken from the steady pack, it suggests that the patient has taken the medicine. This vulnerability isn't ordinarily reasonable in light of the course that there may be conditions where the patient performs such a move without truly making the fix. An event of such a case can be the time when a patient takes the helter-skelter pill and a brief time allotment later comprehends that it isn't the pill he expected to take, all things considered he returns it without using it.

In the present use we attempt to oversee such cases by utilizing essential standards of the shape "if a pill is taken and set back in under 10 seconds carelessness the occasion". Regardless, this isn't the most ideal approach to manage plan with such conditions. In a perfect world we need the capacity to tell precisely if any pills have been expelled from the compartment, and assuming for sure, what number of. The present advancement empowers us to accomplish that with high precision by evaluating the heaviness of the holder prior and after that some time later substitution. The improvement ought to be possible by putting a stack/oblige sensor at the base of the supportive unit. Such sensors are fiscally open and have been utilized as a bit of the past for relative applications. There are driven lights to display the patients and caution besides accommodated exhibit the proportional.

\section{CONCLUSION}

The robotized supportive update framework is beneficial to remind the general open to take as much time as is required. The server holds most of the data about pills and term of attestation which is gotten a handle on by the ace. As it is computerized there won't be any perplexity among the patients to take their cure.

\section{REFERENCES}

1. Gowri Sankaran, B., Karthik, B. \& Vijayaragavan, S.P. 2019, "Weight ward change region plummeting change for square based image huffman coding", International Journal of Innovative Technology and Exploring Engineering, vol. 8, no. 10, pp. 4313-4316.

2. Gowri Sankaran, B., Karthik, B. \& Vijayaragavan, S.P. 2019, "Image compression utilizing wavelet transform", International Journal of Innovative Technology and Exploring Engineering, vol. 8, no. 10, pp. 4305-4308.

3. Kandavel, N. \& Kumaravel, A. 2019, "Offloading computation for efficient energy in mobile cloud computing", International Journal of Innovative Technology and Exploring Engineering, vol. 8, no. 10, pp. 4317-4320.

4. Vinoth, V.V. \& Kanniga, E. 2019, "Reversible data hiding in encrypting images-an system", International Journal of Engineering and Advanced Technology, vol. 8, no. 6, pp. 3051-3053.

5. Selvapriya, B. \& Raghu, B. 2019, "Pseudocoloring of medical images: A research", International Journal of Engineering and Advanced Technology, vol. 8, no. 6, pp. 3712-3716.

6. Senthil Kumar, K. \& Muthukumaravel, A. 2019, "Bi-objective constraint and hybrid optimizer for the test case prioritization", International Journal of Engineering and Advanced Technology, vol. 8, no. 6, pp. 3436-3448.

7. Kavitha, G., Priya, N., Anuradha, C. \& Pothumani, S. 2019, "Read-write, peer-to-peer algorithms for the location-identity split", International Journal of Innovative Technology and Exploring Engineering, vol. 8, no. 9 Special Issue 3, pp. 445-447.

8. Kaliyamurthie, K.P., Michael, G., Anuratha, C. \& Sundaraj, B. 2019, "Certain improvements in alzheimer disease classification using novel fuzzy c means clustering for image segmentation", International Journal of Innovative Technology and Exploring Engineering, vol. 8 , no. 9 Special Issue 3, pp. 599-604.

9. Kaliyamurthie, K.P., Sundarraj, B., Geo, A.V.A. \& Michael, G. 2019 , "RIB: Analysis of I/O automata", International Journal of Innovative Technology and Exploring Engineering, vol. 8, no. 9 Special Issue 3, pp. 1019-1022.

10. Velvizhi, R., Rajabhushanam, C. \& Vidhya, S.R.S. 2019, "Opinion mining for travel route recommendation using Social Media Networks (Twitter)", International Journal of Innovative Technology and Exploring Engineering, vol. 8, no. 9 Special Issue 3, pp. 508-512.

11. Kavitha, R., Sangeetha, S. \& Varghese, A.G. 2019, "Human activity patterns in big data for healthcare applications", International Journal of Innovative Technology and Exploring Engineering, vol. 8, no. 9 Special Issue 3, pp. 1101-1103.

12. Pothumani, S., Anandam, A.K., Sharma, N. \& Franklin, S. 2019, "Extended VEOT framework - Implemented in a smart boutique", International Journal of Innovative Technology and Exploring Engineering, vol. 8, no. 9 Special Issue 3, pp. 762-767.

13. Kaliyamurthie, K.P., Michael, G., Krishnan, R.M.V. \& Sundarraj, B. 2019, "Pseudorandom techniques for the internet", International Journal of Innovative Technology and Exploring Engineering, vol. 8, no. 9 Special Issue 3, pp. 915-918.

14. Aravindasamy, R., Jeffrin Rajan, M., Rama, A. \& Kavitha, P. 2019, "Deep learning provisions in the matlab: Focus on CNN facility", International Journal of Innovative Technology and Exploring Engineering, vol. 8, no. 9 Special Issue 3, pp. 990-994.

15. Theivasigamani, S., Linda, M. \& Amudha, S. 2019, "Object sensing and its identification \& motion sensing", International Journal of Innovative Technology and Exploring Engineering, vol. 8, no. 9 Special Issue 3, pp. 545-549.

16. Mary Linda, I., Vimala, D. \& Shanmuga Priya, K. 2019, "A methodology for the emulation of IPv4", International Journal of Innovative Technology and Exploring Engineering, vol. 8, no. 9 Special Issue 3, pp. 848-852.

17. Velvizhi, R., Priya, D.J., Vimala, D. \& Linda, I.M. 2019, "Increased routing algorithm for mobile adhoc networks", International Journal of Innovative Technology and Exploring Engineering, vol. 8, no. 9 Special Issue 3, pp. 1606-1608.

18. Sangeetha, S., Anuradha, C. \& Priya, N. 2019, "DNS in real world", International Journal of Innovative Technology and 
Exploring Engineering, vol. 8, no. 9 Special Issue 3, pp. 937-940.

19. Geetha, C., Vimala, D. \& Priya, K.S. 2019, "Constructing multi-processors and spreadsheets with SKIVE", International Journal of Innovative Technology and Exploring Engineering, vol. 8, no. 9 Special Issue 3, pp. 516-519.

20. Yugendhar, K., Sugumar, V. \& Kavitha, P. 2019, "A novel method of univac using fuzzy logic", International Journal of Innovative Technology and Exploring Engineering, vol. 8, no. 9 Special Issue 3, pp. $435-437$.

21. Kaliyamurthie, K.P., Michael, G., Elankavi, R. \& Jijo, S.A. 2019, "Implementing aggregate-key for sharing data in cloud environment using cryptographic encryption", International Journal of Innovative Technology and Exploring Engineering, vol. 8, no. 9 Special Issue 3, pp. 957-959.

22. Jeffrin Rajan, M., Aravindasamy, R., Kavitha, P. \& Rama, A. 2019, "A novel method of object orientation variation in $\mathrm{C}++$ and java", International Journal of Innovative Technology and Exploring Engineering, vol. 8, no. 9 Special Issue 3, pp. 708-710.

23. Nayak, R., Dinesh, S. \& Thirunavukkarasu, S. 2019, "A novel method improvement of rapid miner for the data mining applications", International Journal of Innovative Technology and Exploring Engineering, vol. 8, no. 9 Special Issue 3, pp. 457-460.

24. Sivaraman, K., Krishnan, R.M.V., Sundarraj, B. \& Sri Gowthem, S. 2019, "Network failure detection and diagnosis by analyzing syslog and SNS data: Applying big data analysis to network operations", International Journal of Innovative Technology and Exploring Engineering, vol. 8, no. 9 Special Issue 3, pp. 883-887.

25. Vimala, D., Linda, I.M. \& Priya, K.S. 2019, "Decoupling online algorithms from erasure coding in DNS", International Journal of Innovative Technology and Exploring Engineering, vol. 8, no. 9 Special Issue 3, pp. 950-953.

26. Rama, A., Kumaravel, A. \& Nalini, C. 2019, "Preprocessing medical images for classification using deep learning techniques", International Journal of Innovative Technology and Exploring Engineering, vol. 8, no. 9 Special Issue 3, pp. 711-716.

27. Sangeetha, S., Srividhya, S.R., Anita Davamani, K. \& Amudha, S. 2019, "A procedure for avoid overrun error in universal synchronous asynchronous receiver transmitter (usart) by utilizing dummy join and interrupt latency method", International Journal of Innovative Technology and Exploring Engineering, vol. 8, no. 9 Special Issue 3, pp. 657-660.

28. Aravindasamy, R., Jeyapriya, D., Sundarajan, B. \& Sangeetha, S. 2019, "Data duplication in cloud for optimal performance and security", International Journal of Innovative Technology and Exploring Engineering, vol. 8, no. 9 Special Issue 3, pp. 1156-1158.

29. Aravindasamy, R., Jeffrin Rajan, M., Sugumar, V. \& Kavitha, P. 2019, "A novel method on developing superblocks and the transistor using apodryal", International Journal of Innovative Technology and Exploring Engineering, vol. 8, no. 9 Special Issue 3, pp. 982-985.

30. Sasikumar, C.S. \& Kumaravel, A. 2019, "E-learning attributes selection through rough set theory and data mining", International Journal of Innovative Technology and Exploring Engineering, vol. 8 , no. 10 , pp. $3920-3924$

\section{AUTHORS PROFILE}

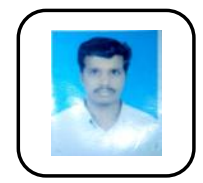

K.Sivaraman AssistantProfessor,Department of CSE,Bharath Institute of Higher Education \& Research,TamilNAdu

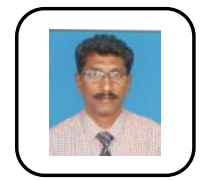

S. Neduncheliyan Professor,Department of CSE,Bharath Institute of Higher Education \& Research,TamilNAdu

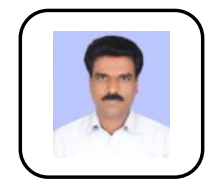

K.P. Kaliyamoorthi Professor,Department of CSE,Bharath Institute of Higher Education \& Research,TamilNAdu 